\title{
Galectin-8 binds to LFA-1, blocks its interaction with ICAM-1 and is counteracted by anti-Gal-8 autoantibodies isolated from lupus patients
}

\author{
Lucas Vicuña ${ }^{1,2}$, Evelyn Pardo ${ }^{1,2}$, Cristóbal Curkovic ${ }^{1,2}$, Remziye Döger ${ }^{1,2}$, Claudia Oyanadel ${ }^{1,2}$, Claudia Metz ${ }^{1,2}$, \\ Loreto Massardo', Alfonso González ${ }^{1,2}$ and Andrea Soza ${ }^{1,2^{*}}$ \\ 1 Departamento de Inmunología Clínica y Reumatología, Facultad de Medicina \\ ${ }^{2}$ Centro de Envejecimiento y Regeneración (CARE), Facultad de Ciencias Biológicas, Pontificia Universidad Católica de Chile, Santiago, Chile.
}

\begin{abstract}
Galectin- 8 belongs to a family of mammalian lectins that recognize glycoconjugates present on different cell surface components and modulate a variety of cellular processes. A role of Gal-8 in the immune system has been proposed based on its effects in immune cells, including $\mathrm{T}$ and B lymphocytes, as well as the presence of anti-Gal-8 autoantibodies in the prototypic autoimmune disease systemic lupus erythematosus (SLE). We have previously described that Gal-8 induces apoptosis in activated T cells interacting with certain $\beta 1$ integrins and this effect is counteracted by the anti-Gal-8 autoantibodies. Given that Gal-8 can potentially interact with several glycoproteins, here we analyzed the $\beta 2$ integrin Lymphocyte Function-Associated Antigen-1 (LFA-1), which is involved in leukocyte cell adhesion and immunological synapses. We show by GST-pull down assays that Gal-8 interacts with LFA-1 and this interaction is inhibited by anti-Gal-8 autoantibodies isolated from SLE patients. In cell adhesion assays, Gal-8 precluded the interaction of LFA-1 with its ligand Intracellular Adhesion Molecule-1 (ICAM-1). These results suggest that Gal-8 can exert immunosuppressive action not only by inducing apoptosis in activated T cells but also by negatively modulating the crucial function of LFA-1 in the immune system, while function-blocking autoantibodies counteract these effects.
\end{abstract}

Key words: Galectin-8, LFA-1, ICAM-1, SLE, autoantibodies.

\section{INTRODUCTION}

Galectins are secreted by an unconventional mechanism and modulate a large variety of cellular processes through cell surface interactions with $\beta$-galactosides present in $\mathrm{N}$ - and O-glycosylated proteins (Di Lella et al., 2011; Kaltner and Gabius, 2012). Their presence in the cytosol before secretion also has functional relevance, as they can exert intracellular actions involving protein-protein or lectin-glycan interactions (Bhagatji et al., 2010; Thurston et al., 2012). Cellular processes that can be modulated by galectin cell surface interactions include cell adhesion, spreading, migration, proliferation, differentiation and apoptosis (Dennis et al., 2009; Boscher et al., 2011; Rabinovich et al., 2012). Galectins also have therapeutic potential by counteracting cellular dysfunctions leading to disease (Rabinovich and Toscano, 2009).

In accordance with the organization of their carbohydrate recognition domains (CRDs), three different groups of galectins are currently distinguished: 1) Prototype galectins (Gal-1, -2, -5,-7, -10,-11,-13, and -15) have one CRD and form homodimeric complexes; 2) Tandem repeat galectins (Gal-4, -6, -8, -9 and -12) have two different CRDs separated by a linker peptide, conforming heterodimer equivalents that can dimerize, leading to tetravalent complexes; 3) A unique chimera type member, Gal-3, has one CRD and a non-lectin domain through which multimers are usually assembled.

Redundant and non-redundant functions of different galectins are accomplished based on the glycan selectivity of their CRDs, subsets of cell surface receptors they recognize and consequential modulation of the corresponding signaling networks (Bi et al., 2008; Lajoie et al., 2009; Boscher et al., 2011; Di Lella et al., 2011; Kaltner and Gabius, 2012). The CRDs of different galectins and even the $\mathrm{N}$-terminal or C-terminal CRDs of tandem repeat galectins display variations which serve to engage different subsets of functionally distinct glycoproteins (Hirabayashi et al., 2002; Ideo et al., 2003; Patnaik et al., 2006; Stillman et al., 2006; Carlsson et al., 2007; Stowell et al., 2008; Ideo et al., 2011). Thus, understanding the functions of a particular galectin requires defining the range of its interacting elements in different cellular contexts.

Gal-8 is one of the most widely expressed galectins in human tissues (Hadari et al., 1995; Bidon et al., 2001) and is also common in cancerous cells (Bidon-Wagner and Le Pennec 2004; Lahm et al., 2004). In the immune system Gal-8 can play important roles in the homeostasis of T- (Cárcamo et al., 2006; Tribulatti et al., 2007; Norambuena et al., 2009; Tribulatti et al., 2009; Tribulatti et al., 2012) and B-cells (Tsai et al., 2011). Gal-8 expression in the thymus and its pro-apoptotic effects on $\mathrm{CD} 4^{\text {high }} \mathrm{CD} 8^{\text {high }}$ thymocytes suggest a role in shaping the $\mathrm{T}$ cell repertoire (Tribulatti et al., 2007). Peripheral T cells respond differentially to Gal-8 depending on their activation stage. In naïve $\mathrm{T}$ cells, Gal-8 at high concentration induces proliferation in the absence of antigen, while at low concentration it costimulates antigen-specific activation (Tribulatti et al., 2009). Once activated, $\mathrm{T}$ cells undergo apoptosis in response to Gal-8, involving an enhanced expression of FasL receptor (Norambuena et al., 2009). In B cells, Gal-8 promotes differentiation toward plasma cells (Tsai et al., 2011), while Chile. Tel: 56-2-6862713; Fax: 56-2-2229995. 
neutrophils respond to this lectin by activating their plasma membrane NADPH-oxidase (Nishi et al., 2003). There is also evidence suggesting an altered Gal-8 function in rheumatic, autoimmune and inflammatory disorders (Nishi et al., 2003; Eshkar Sebban et al., 2007). Patients with SLE, the prototypic autoimmune disease, frequently generate anti-Gal-8 autoantibodies (Pardo et al., 2006) that block adhesion and spreading of Jurkat $\mathrm{T}$ cells in a Gal-8 matrix (Cárcamo et al., 2006). These antibodies also decrease Gal-8-induced apoptosis of Jurkat T cells (Norambuena et al., 2009). To understand the role of Gal- 8 in the immune system and the pathogenic potential of anti-Gal-8 autoantibodies it is necessary to identify functionally relevant Gal-8 counter-receptors.

Gal-8 has been reported to interact with $\alpha 3 \beta 1$ and $\alpha 5 \beta 1$ integrins (Cárcamo et al., 2006), which are both involved in $\mathrm{T}$ cell-driven tissue inflammatory processes (Dustin and de Fougerolles 2001; Pribila et al., 2004). Anti-Gal-8 autoantibodies produced by lupus patients inhibit these interactions (Cárcamo et al., 2006). However, it is very likely that the effects of Gal8 on cells of the immune system do not rely on $\beta 1$ integrins alone. A previous study suggests that $\beta 2$ integrin LFA- 1 is a putative counter-receptor of Gal-8 (Yamamoto et al., 2008). LFA- 1 is composed of $\alpha \mathrm{L}$ and $\beta 2$ subunits; it plays crucial roles in immune cells (Hogg et al., 2011) and autoimmune diseases such as SLE (Zhang et al., 2013) and is overexpressed in T lymphocytes of patients with SLE (Richardson, 2003). LFA-1 is a co-stimulatory molecule in immunological synapses between T lymphocytes and APCs (Kuhlman et al., 1991; Hogg et al., 2011) and mediates lymphocyte adhesion to endothelial cells (Hogg et al., 2002), especially during extravasation in inflamed areas (Sanchez-Madrid and González-Amaro, 2001). It also facilitates the adhesion and migration of naïve and memory $\mathrm{T}$ cells to secondary lymphoid organs (Rossetti et al., 2002). ICAM-1 is the major ligand of LFA-1; it is ubiquitously expressed on most leukocytes and endothelial cells, where it is up-regulated during inflammation (Springer, 1990).

In this study we report that Gal-8 binds to LFA-1 in a carbohydrate-dependent manner, which can be displaced by anti-Gal-8 autoantibodies isolated from SLE patients. We also show that soluble recombinant Gal-8 inhibits the interaction between LFA-1 and its ligand ICAM-1. These results indicate that Gal-8 has the potential to control LFA-1-dependent functions and together with anti-Gal-8 autoantibodies might contribute to modulate immune responses in normal and pathological conditions.

\section{MATERIALS AND METHODS}

\section{Expression of recombinant Gal-8}

Gal-8 with a glutathione S-transferase (GST) tag was prepared as described previously (Cárcamo et al., 2006). Expression of recombinant GST-Gal-8 was induced with $0.2 \mathrm{mM}$ isopropyl-1thio- $\beta$-d-galactopyranoside (Invitrogen, Carlsbad, CA, USA) for 4 h. GST-Gal-8 Glutathione-Sepharose affinity columns were prepared as described by the manufacturer (GE Healthcare, Little Chalfont, Buckinghamshire, United Kingdom).

Cell adhesion assays

Gal-8 released from GST by proteolytic treatment was used in cell adhesion assays (Cárcamo et al., 2006). 96-well tissue culture plates were coated overnight at $4{ }^{\circ} \mathrm{C}$ with $10 \mu \mathrm{g} /$ $\mathrm{ml}$ of Gal-8 or ICAM-1 in PBS and then were blocked by denatured bovine serum albumin (BSA). Serum-starved PBMC (200000 cells/well), pre-incubated in medium free of FBS for $2 \mathrm{~h}$, were suspended in $1 \mathrm{ml}$ of RPMI and plated in wells for the indicated time periods at $37{ }^{\circ} \mathrm{C}$. Adherent cells were washed twice with PBS, stained and fixed with $0.2 \%$ crystal violet (Sigma) and 10\% methanol in $\mathrm{H}_{2} \mathrm{O}$ for $5 \mathrm{~min}$ at room temperature. After removing excess dye by washing with $\mathrm{H}_{2} \mathrm{O}$ and PBS, the cells were solubilized in $0.1 \mathrm{M} \mathrm{NaH}_{2} \mathrm{PO}_{4}$ and $50 \%$ ethanol for $10 \mathrm{~min}$ at room temperature and the absorbance at 570 nanometers was determined. Specific binding was estimated from the difference between cells bound to ligandcoated versus denaturated bovine serum albumin-coated wells. All assays were performed in quadruplicate (mean \pm SD). Statistics were evaluated using Student's t-test.

\section{GST-Gal-8 pull-down assay}

We used a previously described pull-down assay to analyze proteins that interact with Gal-8 (Cárcamo et al., 2006). PBMC were lysed with $1 \% \mathrm{NP}-40$ buffer containing $25 \mathrm{mM}$ Tris-HCl (pH 7.4), $150 \mathrm{mM} \mathrm{NaCl}, 2 \mathrm{mM}$ EDTA, $4 \mu \mathrm{g} / \mathrm{ml}$ leupeptin, $4 \mathrm{mM}$ PMSF, $4 \mu \mathrm{g} / \mathrm{ml}$ antipain and $4 \mu \mathrm{g} / \mathrm{ml}$ pepstatin A (Sigma) for $1 \mathrm{~h}$ at $4{ }^{\circ} \mathrm{C}$. Cell lysates were centrifuged at $14,000 \mathrm{rpm}$ for $10 \mathrm{~min}$ at $4{ }^{\circ} \mathrm{C}$ and supernatants were preincubated with a GST-Sepharose column and then incubated with GST-Sepharose-Gal-8 in the presence or absence of thiodigalactoside (TDG) $(10 \mathrm{mM})$ or anti-Gal-8 antibodies isolated from SLE patients (30 or $60 \mu \mathrm{g} / \mathrm{ml}$ ) for $1 \mathrm{~h}$ at $4{ }^{\circ} \mathrm{C}$. Beads were then washed with PBS, suspended and boiled in loading buffer. Bound $\alpha \mathrm{L}$ integrins were resolved by $10 \%$ SDSPAGE, immunoblotted onto nitrocellulose membranes and visualized by ECL. The results are expressed as mean \pm SD.

Isolation of anti-Gal-8 autoantibodies and depleted IgG fraction

Sera from patients with SLE regularly monitored in the Department of Clinical Immunology and Rheumatology, Faculty of Medicine, Catholic University of Chile were obtained with the consent of the donors from the blood bank of the Hospital of the Catholic University of Chile. Sera were screened by immunoblot for autoantibodies against Gal-8 using $0.5 \mu \mathrm{g}$ of Gal-8 released from GST-Gal-8 as antigen. Sera that gave strong reactivity were used to purify Gal-8 autoantibodies by affinity chromatography with GST-Gal-8 covalently linked to Affi-Gel 10 (BioRad), according to the manufacturer's instructions. Bound antibodies were eluted with $0.1 \mathrm{M}$ glycine- $\mathrm{HCl} \mathrm{pH} 2.5$ solution, neutralized with $1 \mathrm{M}$ $\mathrm{K}_{2} \mathrm{HPO}_{4}$, dialyzed in PBS and maintained in PBS containing 1 $\mathrm{mg} / \mathrm{ml}$ BSA at $-20{ }^{\circ} \mathrm{C}$. The rest of the sera were incubated with protein-A-Sepharose to isolate an IgG fraction depleted from Gal-8 autoantibodies that served as control (C-IgG).

\section{Statistics}

All probability values were obtained using Student`s t-test.

\section{RESULTS}

To study if Gal-8 binds to LFA-1 we performed pull-down assays and immunoblot analyses. Extracts of freshly isolated peripheral 
mononuclear cells (PBMCs) (Fig. 1) were incubated with GSTGal-8 in the presence or absence of TDG as specific blocker of galectin-glycan interactions. Gal-8 clearly bound LFA-1 in a glycan-dependent manner, as it was inhibited by TDG.

We have previously shown that Gal-8 used as a matrix induces a strong adhesion of PBMCs (Cárcamo et al., 2006).
To compare adhesion of PBMCs to Gal- 8 and ICAM-1, PBMCs were seeded on 96-well plates coated with $10 \mu \mathrm{g} / \mathrm{ml}$ of either Gal-8 or ICAM-1 and incubated at $37^{\circ} \mathrm{C}$ for different periods of time (Fig. 2A). After $15 \mathrm{~min}$ of incubation, around $40 \%$ of the cells attached to Gal- 8 , while only $15 \%$ of the cells attached to ICAM-1. After $1 \mathrm{~h}, 100 \%$ of the cells were adhered to Gal- 8
A

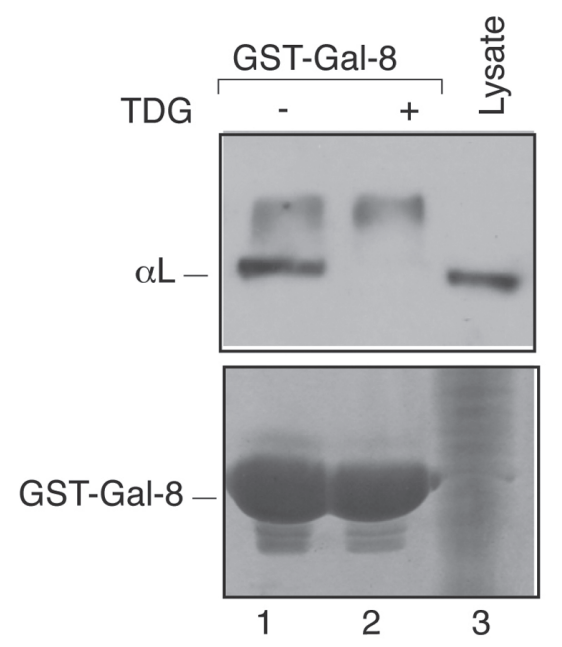

B

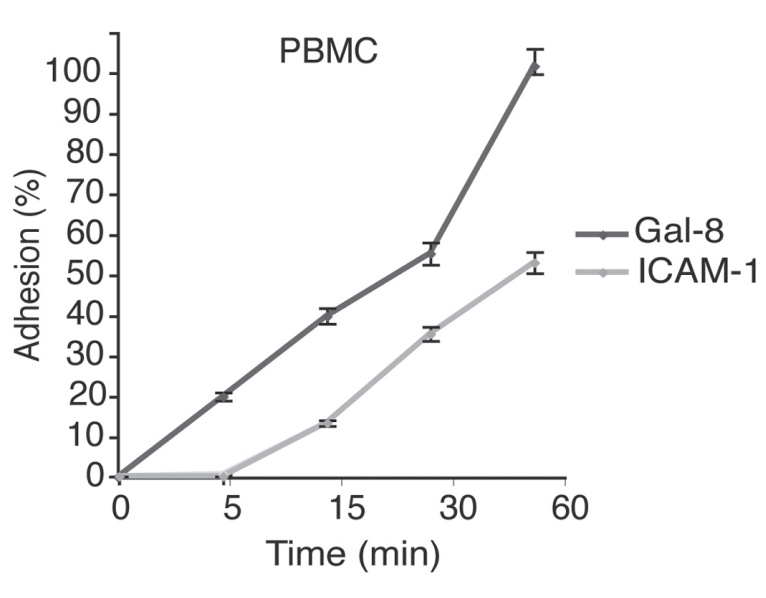

Figure 1. Gal-8 binds to $\boldsymbol{\alpha} \mathbf{L}$ integrin: Affinity chromatography assays were performed incubating PBMC extracts with GST-Gal-8 linked to glutathione-Sepharose in the absence or presence of $10 \mathrm{mM}$ TDG. Bound proteins were analyzed by SDS-PAGE and immunoblot against the indicated integrin. Gal-8 binds to aL integrin, through beta-galactosides, as shown by TDG inhibition. Coomassie staining of GST-Gal-8 and total cell extract are also shown

A

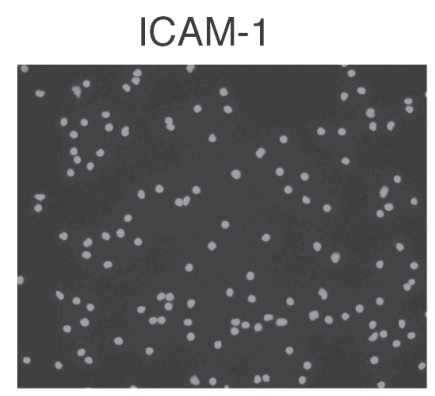

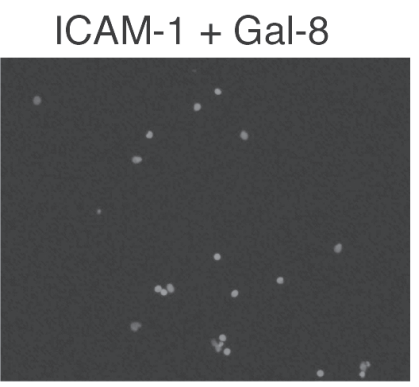

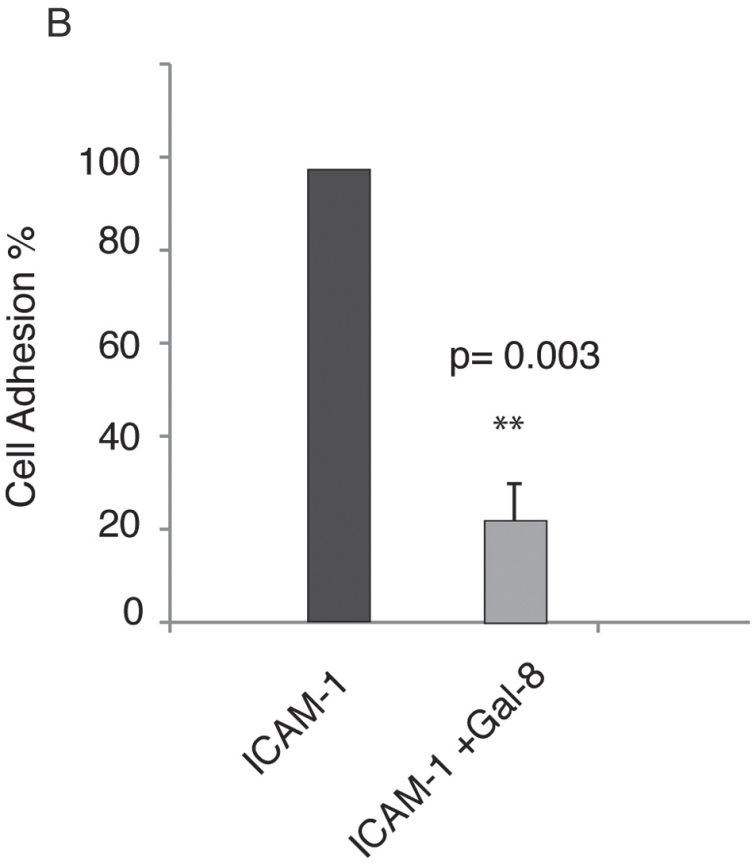

Figure 2. Adhesion of PBMCs to immobilized ICAM-1 is displaced by soluble Gal-8: A) PBMCs (50,000 cells/well) were seeded in serum-free medium on 96-well plates pre-coated with Gal-8 or ICAM-1 $(10 \mu \mathrm{g} / \mathrm{ml})$ and incubated at $37{ }^{\circ} \mathrm{C}$ for the indicated time periods. Adhesion was analyzed by Crystal Violet assay. B) PBMCs pre-incubated with or without soluble Gal-8 were seeded for 30 min on coverslips pre-coated with $10 \mu \mathrm{g} / \mathrm{ml}$ of ICAM-1. Cell nuclei were stained with Hoechst. C) Cell adhesion was quantified by counting cell nuclei in three independent experiments. 
while only $50 \%$ adhered to ICAM-1. When the PBMCs were incubated for $30 \mathrm{~min}$ with $10 \mu \mathrm{g} / \mathrm{ml}$ of soluble Gal-8 and then seeded in ICAM-1 coated plates, adhesion was $80 \%$ inhibited (Fig. 2B and C). This last result indicates that Gal-8 interferes with the interaction of LFA-1 and ICAM-1.

SLE patients produce autoantibodies against Gal-8 with higher frequency than healthy individuals (Pardo et al., 2006). Interestingly, these autoantibodies block adhesion, spreading and apoptosis of Jurkat T cells induced by Gal-8 (Norambuena et al., 2009). Therefore, we analyzed whether these anti-Gal-8 autoantibodies also have the capability to interfere with the interaction between Gal-8 and LFA-1. As shown in pull-down experiments, anti-Gal-8 autoantibodies isolated from the sera samples of three different SLE patients decreased the amount of LFA-1 attached to GST-Gal-8. Using $60 \mu \mathrm{g} / \mathrm{ml}$ (data not shown) the inhibition was similar to the inhibition induced by TDG (Fig. 3, lane 3). In contrast, IgG purified from the same sera after depleting the Gal-8 autoantibodies did not inhibit the interaction of Gal-8 with LFA-1 (Fig. 3, lane 7 and 8). The GST control did not bind to this integrin (Fig. 3, lane 1).

\section{DISCUSSION}

Here we show that Gal-8 interacts with LFA-1 in a carbohydrate-dependent manner and that Gal-8 blocks
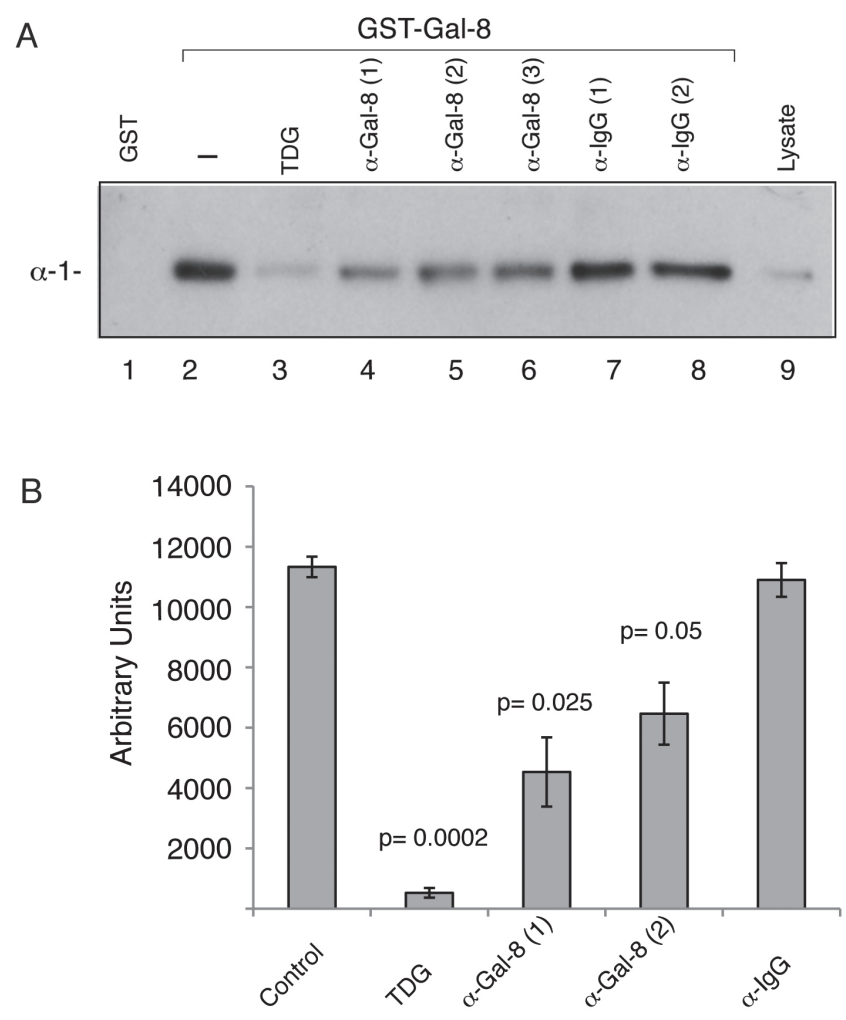

Figure 3. Gal-8 autoantibodies block the interaction between Gal-8 and $\boldsymbol{\alpha} \mathbf{L}$ integrin: A) Affinity chromatography assays show that binding of $\alpha \mathrm{L}$ integrin to GST-Gal-8 attached to glutathioneSepharose (lane 2) is inhibited by anti-Gal-8 autoantibodies isolated from three different patients (lanes 4,5 and 6) but not by two different control anti-IgG antibodies (lanes 7 and 8). B) Quantification of three independent experiments. binding of LFA-1 to ICAM-1. We also show that anti-Gal-8 autoantibodies generated by SLE patients block the interaction of Gal-8 with LFA-1. Therefore, Gal-8 has the potential to modulate negatively the crucial function of LFA- 1 in the immune system and this role of Gal- 8 can be counteracted by Gal-8 autoantibodies.

Previous studies aimed to identify putative Gal-8 counterreceptors detected LFA-1 among other proteins bound to this lectin in affinity chromatography assays (Yamamoto et al., 2008; Tribulatti et al., 2009). However, these studies did not provide evidence of functional implications for this putative interaction. Tribulatti et al., (2009) studied Gal-8 bound proteins by mass spectrometry analysis in mice splenocytes and found several leukocyte surface glycoproteins, including previously reported integrins (Hadari et al., 2000; Zick et al., 2004; Cárcamo et al., 2006; Yamamoto et al., 2008) and CD45, as candidate counter-receptors. Their functional studies then focused on CD45, leaving LFA-1 unexplored (Tribulatti et al., 2009). In Jurkat cells, Yamamoto et al., (2008) reported the interaction between Gal-8 and LFA-1. However, blocking anti- $\beta 2$ antibodies did not interfere with cell adhesion to Gal8 , therefore they concluded that $\alpha \mathrm{L}$ is not a major counterreceptor for Gal-8 (Yamamoto et al., 2008). Instead, their immunoblot and N-terminal amino acid sequence analysis showed $\alpha 4$ integrin as the major target molecule of Gal-8 in Jurkat cell adhesion assays, which was suppressed by both anti- $\alpha 4$ and - $\beta 1$ integrin antibodies (Yamamoto et al., 2008). We previously reported that in Jurkat cells $\alpha 1, \alpha 3$ and $\alpha 5$ but not $\alpha 4$ integrins are the main Gal-8 interacting proteins among $\beta 1$ integrins (Cárcamo et al., 2006). Here we clearly detected that $\alpha \mathrm{L}$ integrin bound to Gal-8 in pull-down experiments and also showed that Gal-8 can block the interaction of LFA-1 with its natural ligand ICAM-1 in cell adhesion. The discrepancies between the results of Yamamoto and ours are likely due to variations in sub-lines of Jurkat cells. However, we also found similar results using PBMCs from healthy people, which contain around $70 \% \mathrm{~T}$ cells, 20\% B cells and 5\% monocytes, all known to express LFA-1 on the cell surface (Martz, 1987). Up to now the interaction with LFA-1 has only been described for Gal-8 and not with any other galectin. Therefore, Gal-8 has the potential to modulate LFA-1 interactions with ICAM-1, and thus might modulate a variety of immunological processes that become dysfunctional in autoimmunity.

LFA-1 mediates lymphocyte cell adhesion and immunological synapses; its altered function plays an important pathogenic role in autoimmunity, particularly in the context of hypomethylated DNA (Zhang et al., 2013). Initial studies found that $\alpha \mathrm{L}$ integrin expression is increased in $\mathrm{T}$ cells of patients with active SLE, in correlation with their hypomethylated genomic DNA (Richardson et al., 1992). LFA1 overexpression in normal $\mathrm{T}$ cells is induced by inhibition of DNA methylation with 5-azacytidine (5-azaC) (Richardson et al., 1992). Overexpression of $\alpha \mathrm{L}$ integrin in $\mathrm{T}$ cells resulting either from DNA methylation inhibition or from transfection with $\beta 2$ integrin cDNA leads to $\mathrm{T}$ cell autoreactivity in vitro (Richardson et al., 1994). Adoptive transfer of these cells results in lupus-like disease in mice (Yung et al., 1996). A similar effect is achieved with $\mathrm{T}$ cells treated with 5-azaC or procainamide, thus mimicking drug induced lupus-like syndromes (Quddus et al., 1993). Furthermore, specific sequences flanking the promoter of the gene encoding aL were found hypomethylated in $\mathrm{T}$ cells from patients with active 
lupus and in $\mathrm{T}$ cells treated with 5 -azaC and procainamide (Lu et al., 2002). Recently, two miRNAs (miR-21 and miR148a) that promote cell DNA hypomethylation were found highly elevated in CD4 T cells of SLE patients and in a lupus mouse model (MRL/lpr), together with overexpression of methylation-sensitive genes including LFA-1 (Pan et al., 2010). On the other hand, conditions that decrease LFA-1 function usually diminish autoimmune reactions. For instance, loss of LFA-1 expression in a lupus mouse model (MRL / MPJ-Fas (Ipr) significantly inhibits the development of inflammatory disease (Kevil et al., 2004) and treatment of NZB/NZW F-1 lupus mice with blocking LFA-1 antibodies inhibits autoantibody production characteristic of lupus (Connolly et al., 1994). LFA-1-blocking antibodies also inhibit the development of autoimmune diseases such as diabetes (Bertry-Coussot et al., 2002), experimental autoimmune encephalitis (EAE) (Gordon et al., 1995) and glomerulonephritis (Nishikawa et al., 1993) in different animal models. All these data indicate that incremented LFA-1 function promotes autoimmune disorders, whereas the contrary occurs when LFA-1 function decreases. Therefore, in addition to inducing apoptosis of activated $\mathrm{T}$ cells (Norambuena et al., 2009), Gal-8 might also exert an immunosuppressive action by blocking LFA-1 function. It has been reported that Gal-8 is endocytosed after binding to the cell surface (Carlsson et al., 2007), thus Gal-8 may remove LFA1 from the cell surface and inhibit its interaction with ICAM-1.

SLE patients are known to produce more than a hundred different autoantibodies (Sherer et al., 2004), but only a few of them have been directly related to pathogenic mechanisms (Matus, et al., 2007; Tsokos, 2011). We have previously shown that anti-Gal-8 autoantibodies produced by SLE patients block the interaction of Gal-8 with $\beta 1$ integrins involved in its apoptotic action upon activated $\mathrm{T}$ cells (Norambuena et al., 2009). Autoantibodies against different members of the galectin family such as Gal-1, $-2,-3$, and -4 been detected in patients with different types of autoimmune diseases and in cancer (Lutomski et al., 1997; Giordanengo et al., 2001; Jensen-Jarolim et al., 2001; Lim et al., 2002; Romero et al., 2006; Montiel et al., 2010). However, whether autoantibodies against galectins interfere with galectin function in the immune system and whether they play pathogenic roles are poorly studied. Recently decrease in Gal-1 in synovial fluids in Rheumatoid Arthritis (RA) patients was correlated with a significant increase in Gal-1 autoantibodies, suggesting a physiological effect of these autoantibodies limiting the amount of Gal-1 and potentially blocking its biological effect in RA patients (XibilleFriedmann et al., 2013).

Here, we show that these anti-Gal- 8 autoantibodies also block the interaction of Gal-8 with LFA-1, thus providing further evidence of a potential pathogenic role for these autoantibodies.

\section{ACKNOWLEDGEMENTS}

This work received financial support from CONICYT grant\# PFB12 / 2007 and FONDECYT grant\#1100921.

\section{REFERENCES}

BERTRY-COUSSOT L, LUCAS B, DANEL C, HALBWACHS-MECARELLI L, BACH JF, CHATENOUD L, LEMARCHAND P (2002) Long-term reversal of established autoimmunity upon transient blockade of the
LFA-1 / intercellular adhesion molecule-1 pathway. J Immunol 168:36413648.

BHAGATJI P, LEVENTIS R, RICH R, LIN CJ, SILVIUS JR (2010) Multiple cellular proteins modulate the dynamics of K-ras association with the plasma membrane. Biophys J 99:3327-3335.

BI S, EARL LA, JACOBS L, BAUM LG (2008) Structural features of galectin-9 and galectin- 1 that determine distinct $\mathrm{T}$ cell death pathways. $\mathrm{J}$ Biol Chem 283:12248-12258.

BIDON N, BRICHORY F, BOURGUET P, LE PENNEC JP, DAZORD L (2001) Galectin-8: a complex sub-family of galectins (Review). Int J Mol Med $8: 245-250$.

BIDON-WAGNER N, LE PENNEC JP (2004) Human galectin-8 isoforms and cancer. Glycoconj J 19:557-563.

BOSCHER C, DENNIS JW, NABI IR (2011) Glycosylation, galectins and cellular signaling. Curr Opin Cell Biol 23:383-392.

CÁRCAMO C, PARDO E, OYANADEL C, BRAVO-ZEHNDER M, BULL P, CÁCERES M, MARTÍNEZ J, MASSARDO L, JACOBELLI S, GONZÁLEZ A, SOZA A (2006) Galectin-8 binds specific beta1 integrins and induces polarized spreading highlighted by asymmetric lamellipodia in Jurkat T cells. Exp Cell Res 312:374-386.

CARLSSON S, CARLSSON MC, LEFFLER H (2007) Intracellular sorting of galectin- 8 based on carbohydrate fine specificity. Glycobiology.

CARLSSON S, OBERG CT, CARLSSON MC, SUNDIN A, NILSSON UJ, SMITH D, CUMMINGS RD, ALMKVIST J, KARLSSON A, LEFFLER H (2007) Affinity of galectin-8 and its carbohydrate recognition domains for ligands in solution and at the cell surface. Glycobiology 17:663-676.

CONNOLLY MK, KITCHENS EA, CHAN B, JARDIEU P, WOFSY D (1994) Treatment of murine lupus with monoclonal antibodies to lymphocyte function-associated antigen-1: dose-dependent inhibition of autoantibody production and blockade of the immune response to therapy. Clin Immunol Immunopathol 72:198-203.

DENNIS JW, LAU KS, DEMETRIOU M, NABI IR (2009) Adaptive regulation at the cell surface by N-glycosylation. Traffic 10:1569-1578.

DI LELLA S, SUNDBLAD V, CERLIANI JP, GUARDIA CM, ESTRIN DA, VASTA GR, RABINOVICH GA (2011) When galectins recognize glycans: from biochemistry to physiology and back again. Biochemistry 50:78427857.

DUSTIN ML, DE FOUGEROLLES AR (2001) Reprogramming T cells: the role of extracellular matrix in coordination of $\mathrm{T}$ cell activation and migration. Curr Opin Immunol 13:286-290.

ESHKAR SEBBAN L, RONEN D, LEVARTOVSKY D, ELKAYAM O, CASPI D, AAMAR S, AMITAL H, RUBINOW A, GOLAN I, NAOR D, ZICK Y, GOLAN I (2007) The involvement of CD44 and its novel ligand galectin-8 in apoptotic regulation of autoimmune inflammation. J Immunol 179:1225-1235.

GIORDANENGO L, GEA S, BARBIERI G, RABINOVICH GA (2001) Antigalectin-1 autoantibodies in human Trypanosoma cruzi infection: differential expression of this beta-galactoside-binding protein in cardiac Chagas' disease. Clin Exp Immunol 124:266-273.

GORDON EJ, MYERS KJ, DOUGHERTY JP, ROSEN H, RON Y (1995) Both anti-CD11a (LFA-1) and anti-CD11b (MAC-1) therapy delay the onset and diminish the severity of experimental autoimmune encephalomyelitis. J Neuroimmunol 62:153-160.

HADARI YR, ARBEL-GOREN R, LEVY Y, AMSTERDAM A, ALON R, ZAKUT R, ZICK Y (2000) Galectin-8 binding to integrins inhibits cell adhesion and induces apoptosis. J Cell Sci 113:2385-2397.

HADARI YR, PAZ K, DEKEL R, MESTROVIC T, ACCILI D, ZICK Y (1995) Galectin-8. A new rat lectin, related to galectin-4. J Biol Chem 270:34473453.

HIRABAYASHI J, HASHIDATE T, ARATA Y, NISHI N, NAKAMURA T, HIRASHIMA M, URASHIMA T, OKA T, FUTAI M, MULLER WE, YAG F, KASAI K (2002) Oligosaccharide specificity of galectins: a search by frontal affinity chromatography. Biochim Biophys Acta 1572:232-254.

HOGG N, HENDERSON R, LEITINGER B, MCDOWALL A, PORTER I, STANLEY P (2002) Mechanisms contributing to the activity of integrins on leukocytes. Immunol Rev 186:164-171.

HOGG N, PATZAK I, WILLENBROCK F (2011) The insider's guide to leukocyte integrin signalling and function. Nat Rev Immunol 11:416426.

IDEO H, MATSUZAKA T, NONAKA T, SEKO A, YAMASHITA K (2011) Galectin-8-N-domain recognition mechanism for sialylated and sulfated glycans. J Biol Chem 286:11346-11355.

IDEO H, SEKO A, ISHIZUKA I, YAMASHITA K (2003) The N-terminal carbohydrate recognition domain of galectin-8 recognizes specific glycosphingolipids with high affinity. Glycobiology 13:713-723. 
JENSEN-JAROLIM E, NEUMANN C, OBERHUBER G, GSCHEIDLINGER R, NEUCHRIST C, REINISCH W, ZUBERI RI, PENNER E, LIU FT, BOLTZ-NITULESCU G (2001) Anti-Galectin-3 IgG autoantibodies in patients with Crohn's disease characterized by means of phage display peptide libraries. J Clin Immunol 21:348-356.

KALTNER H, GABIUS HJ (2012) A toolbox of lectins for translating the sugar code: the galectin network in phylogenesis and tumors. Histol Histopathol 27:397-416.

KEVIL CG, HICKS MJ, HE X, ZHANG J, BALLANTYNE CM, RAMAN C, SCHOEB TR, BULLARD DC (2004) Loss of LFA-1, but not Mac-1, protects MRL/MpJ-Fas(lpr) mice from autoimmune disease. Am J Pathol 165:609-616

KUHLMAN P, MOY VT, LOLLO BA, BRIAN AA (1991) The accessory function of murine intercellular adhesion molecule-1 in T lymphocyte activation. Contributions of adhesion and co-activation. J Immunol 146:1773-1782.

LAHM H, ANDRE S, HOEFLICH A, KALTNER H, SIEBERT HC, SORDAT B, VON DER LIETH CW, WOLF E, GABIUS HJ (2004) Tumor galectinology: insights into the complex network of a family of endogenous lectins. Glycoconj J 20:227-238.

LAJOIE P, GOETZ JG, DENNIS JW, NABI IR (2009) Lattices, rafts, and scaffolds: domain regulation of receptor signaling at the plasma membrane. J Cell Biol 185:381-385.

LIM Y, LEE DY, LEE S, PARK SY, KIM J, CHO B, LEE H, KIM HY, LEE E, SONG YW, JEOUNG DI (2002) Identification of autoantibodies associated with systemic lupus erythematosus. Biochem Biophys Res Commun 295:119-124.

LU Q, KAPLAN M, RAY D, RAY D, ZACHAREK S, GUTSCH D, RICHARDSON B (2002) Demethylation of ITGAL (CD11a) regulatory sequences in systemic lupus erythematosus. Arthritis Rheum 46:12821291.

LUTOMSKI D, JOUBERT-CARON R, LEFEBURE C, SALAMA J, BELIN C, BLADIER D, CARON M (1997) Anti-galectin-1 autoantibodies in serum of patients with neurological diseases. Clin Chim Acta 262:131-138.

MARTZ E (1987) LFA-1 and other accessory molecules functioning in adhesions of T and B lymphocytes. Hum Immunol 18:3-37.

MATUS S, BURGOS PV, BRAVO-ZEHNDER M, KRAFT R, PORRAS OH, FARÚAS P, BARROS LF, TORREALBA F, MASSARDO L, JACOBELLI $S$, GONZÁLEZ A (2007) Antiribosomal-P autoantibodies from psychiatric lupus target a novel neuronal surface protein causing calcium influx and apoptosis. J Exp Med 204:3221-3234.

MONTIEL JL, MONSIVAIS-URENDA A, FIGUEROA-VEGA N, MOCTEZUMA JF, BURGOS-VARGAS R, GONZÁLEZ-AMARO R, ROSENSTEIN Y (2010) Anti-CD43 and anti-galectin-1 autoantibodies in patients with systemic lupus erythematosus. Scand J Rheumatol 39:50-57.

NISHI $\mathrm{N}$, SHOJI H, SEKI M, ITOH A, MIYANAKA H, YUUBE $\mathrm{K}$ HIRASHIMA M, NAKAMURA T (2003) Galectin-8 modulates neutrophil function via interaction with integrin alphaM. Glycobiology 13:755-763.

NISHIKAWA K, GUO YJ, MIYASAKA M, TAMATANI T, COLLINS AB, SY MS, MCCLUSKEY RT, ANDRES G (1993) Antibodies to intercellular adhesion molecule $1 /$ lymphocyte function-associated antigen 1 prevent crescent formation in rat autoimmune glomerulonephritis. J Exp Med 177:667-677.

NORAMBUENA A, METZ C, VICUNA L, SILVA A, PARDO E, OYANADEL C, MASSARDO L, GONZÁLEZ A, SOZA A (2009) Galectin-8 induces apoptosis in Jurkat $T$ cells by phosphatidic acid-mediated ERK1/2 activation supported by protein kinase A down-regulation. J Biol Chem 284:12670-12679.

PAN W, ZHU S, YUAN M, CUI H, WANG L, LUO X, LI J, ZHOU H, TANG Y, SHEN N (2010) MicroRNA-21 and microRNA-148a contribute to DNA hypomethylation in lupus CD4+ T cells by directly and indirectly targeting DNA methyltransferase 1. J Immunol 184:6773-6781.

PARDO E, CÁRCAMO C, MASSARDO L, MEZZANO V, JACOBELLI S, GONZÁLEZ A, SOZA A (2006) [Antibodies against galectin-8 in patients with systemic lupus erythematosus]. Rev Med Chil 134:159-166

PATNAIK SK, POTVIN B, CARLSSON S, STURM D, LEFFLER H, STANLEY $\mathrm{P}$ (2006) Complex N-glycans are the major ligands for galectin- $1,-3$, and -8 on Chinese hamster ovary cells. Glycobiology 16:305-317.

PRIBILA JT, QUALE AC, MUELLER KL, SHIMIZU Y (2004) Integrins and T cell-mediated immunity. Annu Rev Immunol 22:157-180.

QUDDUS I, JOHNSON KJ, GAVALCHIN I, AMENTO EP, CHRISP CE, YUNG RL, RICHARDSON BC (1993) Treating activated CD4+ T cells with either of two distinct DNA methyltransferase inhibitors, 5-azacytidine or procainamide, is sufficient to cause a lupus-like disease in syngeneic mice. J Clin Invest 92:38-53.
RABINOVICH GA, TOSCANO MA (2009) Turning 'sweet' on immunity: galectin-glycan interactions in immune tolerance and inflammation. Nat Rev Immunol 9:338-352.

RABINOVICH GA, VAN KOOYK Y, COBB BA (2012) Glycobiology of immune responses. Ann N Y Acad Sci 1253:1-15.

RICHARDSON B (2003) DNA methylation and autoimmune disease. Clin Immunol 109:72-79.

RICHARDSON B, POWERS D, HOOPER F, YUNG RL, O'ROURKE K (1994) Lymphocyte function-associated antigen 1 overexpression and $\mathrm{T}$ cell autoreactivity. Arthritis Rheum 37:1363-1372.

RICHARDSON BC, STRAHLER JR, PIVIROTTO TS, QUDDUS J, BAYLISS GE, GROSS LA, O'ROURKE KS, POWERS D, HANASH SM, JOHNSON MA (1992) Phenotypic and functional similarities between 5-azacytidine-treated $\mathrm{T}$ cells and a $\mathrm{T}$ cell subset in patients with active systemic lupus erythematosus. Arthritis Rheum 35:647-662.

ROMERO MD, MUINO JC, BIANCO GA, FERRERO M, JUÁREZ CP, LUNA JD, RABINOVICH GA (2006) Circulating anti-galectin-1 antibodies are associated with the severity of ocular disease in autoimmune and infectious uveitis. Invest Ophthalmol Vis Sci 47:1550-1556.

ROSSETTI G, COLLINGE M, BENDER JR, MOLTENI R, PARDI R (2002) Integrin-dependent regulation of gene expression in leukocytes. Immunol Rev 186:189-207.

SANCHEZ-MADRID F, GONZÁLEZ-AMARO R (2001) Drugs, inflammation and cell adhesion receptors. Expert Opin Pharmacother 2:3-17.

SHERER Y, GORSTEIN A, FRITZLER MJ, SHOENFELD Y (2004) Autoantibody explosion in systemic lupus erythematosus: more than 100 different antibodies found in SLE patients. Semin Arthritis Rheum 34:501-537.

SPRINGER TA (1990) Adhesion receptors of the immune system. Nature 346:425-434.

STILLMAN BN, HSU DK, PANG M, BREWER CF, JOHNSON P, LIU FT, BAUM LG (2006) Galectin-3 and galectin-1 bind distinct cell surface glycoprotein receptors to induce T cell death. J Immunol 176:778-789.

STOWELL SR, ARTHUR CM, SLANINA KA, HORTON JR, SMITH DF, CUMMINGS RD (2008) Dimeric galectin-8 induces phosphatidylserine exposure in leukocytes through polylactosamine recognition by the carboxyl terminal domain. J Biol Chem.

THURSTON TL, WANDEL MP, VON MUHLINEN N, FOEGLEIN A RANDOW F (2012) Galectin 8 targets damaged vesicles for autophagy to defend cells against bacterial invasion. Nature 482:414-418.

TRIBULATTI MV, CATTANEO V, HELLMAN U, MUCCI J, CAMPETELLA O (2009) Galectin-8 provides costimulatory and proliferative signals to T lymphocytes. J Leukoc Biol 86:371-380.

TRIBULATTI MV, FIGINI MG, CARABELLI J, CATTANEO V, CAMPETELLA O (2012) Redundant and antagonistic functions of galectin-1, -3 , and -8 in the elicitation of $\mathrm{T}$ cell responses. J Immunol 188:2991-2999.

TRIBULATTI MV, MUCCI J, CATTANEO V, AGUERO F, GILMARTIN T, HEAD SR, CAMPETELLA O (2007) Galectin-8 induces apoptosis in the CD4(high)CD8(high) thymocyte subpopulation. Glycobiology 17:14041412.

TSAI CM, GUAN CH, HSIEH HW, HSU TL, TU Z, WU KJ, LIN CH, LIN KI (2011) Galectin-1 and galectin-8 have redundant roles in promoting plasma cell formation. J Immunol 187:1643-1652.

TSOKOS GC (2011) Systemic lupus erythematosus. N Engl J Med 365:21102121.

XIBILLE-FRIEDMANN D, BUSTOS RIVERA-BAHENA C, ROJASSERRANO J, BURGOS-VARGAS R, MONTIEL-HERNÁNDEZ JL (2013) A decrease in galectin-1 (Gal-1) levels correlates with an increase in anti-Gal-1 antibodies at the synovial level in patients with rheumatoid arthritis. Scand J Rheumatol 42:102-107.

YAMAMOTO H, NISHI N, SHOJI H, ITOH A, LU LH, HIRASHIMA M, NAKAMURA T (2008) Induction of cell adhesion by galectin- 8 and its target molecules in Jurkat T-cells. J Biochem 143:311-324.

YUNG R, POWERS D, JOHNSON K, AMENTO E, CARR D, LAING T, YANG J, CHANG S, HEMATI N, RICHARDSON B (1996) Mechanisms of drug-induced lupus. II. T cells overexpressing lymphocyte functionassociated antigen 1 become autoreactive and cause a lupuslike disease in syngeneic mice. J Clin Invest 97:2866-2871.

ZHANG Y, ZHAO M, SAWALHA AH, RICHARDSON B, LU Q (2013) Impaired DNA methylation and its mechanisms in CD4(+)T cells of systemic lupus erythematosus. J Autoimmun 41:92-99.

ZICK Y, EISENSTEIN M, GOREN RA, HADARI YR, LEVY Y, RONEN D (2004) Role of galectin-8 as a modulator of cell adhesion and cell growth. Glycoconj J 19:517-526. 